\title{
Pleading Voices Behind Bars: Health Equity for Detainees During the COVID-19 Pandemic in the Philippines
}

\author{
Dalmacito A. Cordero Jr. \\ Department of Theology and Religious Education, De La Salle University, Manila, Philippines
}

\section{Dear Editor,}

In a recent special article published in this journal, the authors described the Korean government's performance in battling the coronavirus disease 2019 (COVID-19) pandemic as relatively good in terms of non-pharmaceutical interventions, such as social distancing and wearing masks, along with testing, tracing, and treatment. However, they also emphasized that little attention has been paid to health equity in measures to control the pandemic by considering social determinants of health such as poor housing, precarious working conditions, disrupted healthcare services, and suspension of social services. With this, they proposed that a people-centered perspective can be a key approach to address the problem [1]. This article is indeed an honest observation and evaluation regarding the inequality of health services that are supposed to be provided to all citizens of Korea during this health crisis. However, I would like to point out that this is a global concern that needs immediate attention from every national government.

A perfect example of this is the situation of our detained community members or those behind bars because of crimes committed. In another study, the authors clearly described the serious situation of an increasing number of prisoners in China, Iran, and the United States who were infected with COV-

Corresponding author: Dalmacito A. Cordero Jr. Department of Theology and Religious Education, De La Salle University, 2401 Taft Avenue, Manila 1004, Philippines E-mail: dalmacito.cordero@dlsu.edu.ph

This is an Open Access article distributed under the terms of the Creative Commons Attribution Non-Commercial License (https://creativecommons.org/licenses/bync/4.0// which permits unrestricted non-commercial use, distribution, and reproduction in any medium, provided the original work is properly cited.
ID-19. They claimed that failure to develop a comprehensive plan as an effective response to the pandemic would be akin to cruel and unusual punishment [2]. Their suggestion of jail/ prison population reduction, as in the United States, by prioritizing the release of older adults, the chronically or seriously ill, and pregnant women is indeed a wise and compassionate strategy to address the problem. I wish that this move could also be imitated in the Philippines, but more consideration should be taken.

The Philippines has the highest jail occupancy rate in the world, as thousands of people have been jailed as a result of the government's "war on drugs." At the start of the pandemic, the arrests and temporary detention of thousands of people for violating curfews and quarantine regulations further crowded police lockups and jails. The combined population in prisons was 215000 as of November 2019, although all the facilities combined have a maximum capacity of only 40000 . This means that a whopping 467 jails nationwide were at $534 \%$ of capacity, indicating massive overcrowding [3]. A cell meant for 2 people is occupied by 11 people in most cases. The government must not only reduce the population in these facilities by releasing older adults, the seriously ill, and pregnant women, but also those who were detained or convicted for petty, questionable, and even non-violent offenses. Those who are near the end of their sentence and those still waiting for the result of their trial for a long time should also be freed. It is important to note that there is substantial controversy regarding how the justice system works and human rights are violated during the current administration. In addition, most prisons do not have the capacity to provide adequate health services for sick inmates. In fact, more than 300 COVID-19 cas- 
es were confirmed among those detainees in May 2020, most in the detention facilities in Cebu, southern Philippines; at least 4 detainees died from the virus, while dozens of people working in prisons also tested positive for the virus [4].

In this scenario, where there is an unimaginable excess of detained people relative to prison capacity, the most reasonable approach is to release as many qualified detainees as possible based on the categories mentioned. This intervention is for the common good of inmates, custodial facility workers, and the entire community. The conditions of overcrowding, poor ventilation, and inadequate medical services make virus transmission easier. We do not want more people to suffer and die, regardless of whether they are free or behind bars. These people are also human beings who are worthy of equal treatment, and their rights must be respected. They need our utmost care since they do not enjoy the external freedom that the majority of us have. In the words of Nelson Mandela, "It is said that no one truly knows a nation until one has been inside its jails. A nation should not be judged by how it treats its highest citizens, but its lowest ones." We all deserve to live and be given a chance to survive in these trying times and not just wait for the crisis to succumb us.

\section{CONFLICT OF INTEREST}

The author has no conflicts of interest associated with the material presented in this paper.

\section{ORCID}

Dalmacito A. Cordero Jr. https://orcid.org/0000-0001-80621242

\section{REFERENCES}

1. Choi H, Kim SY, Kim JW, Park Y, Kim MH; Working Group for the People's Report on COVID-19 in Korea. Mainstreaming of health equity in infectious disease control policy during the COVID-19 pandemic era. J Prev Med Public Health 2021;54(1): 1-7.

2. Barnert $E$, Ahalt $C$, Williams B. Prisons: amplifiers of the COVID19 pandemic hiding in plain sight. Am J Public Health 2020; 110(7):964-966.

3. Human Rights Watch. Philippines: reduce crowded jails to stop COVID-19: release low-level offenders; prioritize older and ill prisoners; 2020 [cited 2021 Sep 23]. Available from: https://www.hrw.org/news/2020/04/06/philippines-reducecrowded-jails-stop-covid-19.

4. Santos AP. 'Waiting to die': coronavirus enters congested Philippine jails. Al Jazeera; 2020 May 4 [cited 2021 Sep 24]. Available from: https://www.aljazeera.com/news/2020/5/4/waiting-to-die-coronavirus-enters-congested-philippine-jails. 